\title{
Inhibition of A-Type Potassium Current by the Peptide Toxin SNX-482
}

\author{
Tilia Kimm and Bruce P. Bean \\ Department of Neurobiology, Harvard Medical School, Boston, Massachusetts 02115
}

SNX-482, a peptide toxin isolated from tarantula venom, has become widely used as an inhibitor of Cav2.3 voltage-gated calcium channels. Unexpectedly, we found that SNX-482 dramatically reduced the A-type potassium current in acutely dissociated dopamine neurons from mouse substantia nigra pars compacta. The inhibition persisted when calcium was replaced by cobalt, showing that it was not secondary to a reduction of calcium influx. Currents from cloned Kv4.3 channels expressed in HEK-293 cells were inhibited by SNX-482 with an $\mathrm{IC}_{50}$ of $<3 \mathrm{~nm}$, revealing substantially greater potency than for SNX-482 inhibition of Cav2.3 channels (IC $5020-60 \mathrm{nm)}$. At sub-saturating concentrations, SNX-482 produced a depolarizing shift in the voltage dependence of activation of Kv4.3 channels and slowed activation kinetics. Similar effects were seen on gating of cloned Kv4.2 channels, but the inhibition was less pronounced and required higher toxin concentrations. These results reveal SNX-482 as the most potent inhibitor of Kv4.3 channels yet identified. Because of the effects on both Kv4.3 and Kv4.2 channels, caution is needed when interpreting the effects of SNX-482 on cells and circuits where these channels are present.

Key words: Cav2.3; $\mathrm{I}_{\mathrm{A}}$; ICK toxin; Kv4.2; Kv4.3; tarantula toxin

\section{Introduction}

Mammalian neurons express many different types of voltagedependent sodium, calcium, and potassium channels. The diversity of ion channel properties and expression patterns allows for complex and finely-tuned regulation of activity in the nervous system (Llinás, 1988; Hille, 2001). Specific inhibitors of ion channels are critical tools for understanding the functions of different channel types. Among voltage-dependent calcium channels, a variety of small-molecule inhibitors and peptide toxins have allowed discrimination of different components of overall calcium current and functional roles of particular calcium channel types (Lacinová et al., 2000; Doering and Zamponi, 2003; McDonough, 2007), and some calcium channel blockers are of clinical interest (Lewis et al., 2012; Nimmrich and Gross, 2012; Vink and Alewood, 2012). SNX-482 is a peptide toxin originally isolated from venom of the tarantula Hysterocrates gigas and found to inhibit Cav2.3 channels with an $\mathrm{IC}_{50}$ of $\sim 30 \mathrm{nM}$, with at least 10 -fold selectivity relative to effects on other calcium channel types (Newcomb et al., 1998). Subsequently, SNX-482 has been widely

\footnotetext{
Received Jan. 24, 2014; revised April 30, 2014; accepted May 27, 2014.

Author contributions: T.K. and B.P.B. designed research; T.K. performed research; T.K. analyzed data; T.K. and B.P.B. wrote the paper.

This work was supported by National Institute of Neurological Disorders and Stroke R01NS036855 and F31NS080323. We thank Dr. Jeanne Nerbonne (Washington University School of Medicine), Dr. Ligia Toro (David Geffen School of Medicine at University of California, Los Angeles), and Dr. Gerald Zamponi (University of Calgary) for generous gifts of cell lines and plasmids, and Dr. Gui-lan Yao for help with cell culture and transfection.

The authors declare no competing financial interests.

Correspondence should be addressed to Dr. Bruce P. Bean, Harvard Medical School, 220 Longwood Avenue, Boston, MA 02115. E-mail: bruce_bean@hms.harvard.edu.

DOI:10.1523/JNEUROSCI.0339-14.2014

Copyright $\odot 2014$ the authors $\quad 0270-6474 / 14 / 349182-08 \$ 15.00 / 0$
}

used to identify currents from Cav2.3 channels and to investigate their functions in cells and circuits (Pringos et al., 2011).

In initial studies on selectivity of the toxin, SNX-482 was found to have no effect on a variety of potassium currents, including native potassium currents in retinal ganglion neurons, IMR-32 neuroblastoma cells, and cloned Kv1.1 and Kv1.4 channels (Newcomb et al., 1998). However, in exploring possible contributions of calcium entry through Cav2.3 channels to activation of potassium currents in midbrain dopamine neurons, we found that SNX-482 completely eliminated a large component of transient potassium current corresponding to A-type potassium current $\left(\mathrm{I}_{\mathrm{A}}\right)$. Further experiments showed that this effect of SNX-482 was not calcium-dependent and was consistent with direct inhibition of Kv4.3 channels. Cloned Kv4.3 channels were inhibited with an $\mathrm{IC}_{50}$ of $<3 \mathrm{~nm}$. Kv4.2 channels were also affected, but to a lesser degree and at higher toxin concentrations.

\section{Materials and Methods}

Acute dissociation of substantia nigra dopaminergic neurons. Dissociated dopamine neurons were prepared from 14- to 19-day-old male and female mice. Mice were anesthetized with isoflurane and decapitated; the brain was quickly removed into ice-cold solution containing (in $\mathrm{mm}$ ) the following: $110 \mathrm{NaCl}, 2.5 \mathrm{KCl}, 10$ HEPES, 25 glucose, 75 sucrose, 7.5 $\mathrm{MgCl}_{2}, \mathrm{pH}$ adjusted to 7.4 with $\mathrm{NaOH}$ and bubbled with $95 / 5 \% \mathrm{O}_{2} / \mathrm{CO}_{2}$. In the same solution, $200 \mu \mathrm{m}$ coronal slices were cut using a vibratome (DSK model DTK-1000; Dosaka). The substantia nigra pars compacta (SNc) was subsequently dissected out of each slice and rinsed in dissociation solution containing (in $\mathrm{mM}$ ) the following: $82 \mathrm{Na}_{2} \mathrm{SO}_{4}, 30 \mathrm{~K}_{2} \mathrm{SO}_{4}, 5$ $\mathrm{MgCl}_{2}, 10$ glucose, 10 HEPES, $\mathrm{pH}$ adjusted to 7.4 with $\mathrm{NaOH}$.

After dissection, the pieces of the SNc were incubated for $8 \mathrm{~min}$ at $34^{\circ} \mathrm{C}$ in $3 \mathrm{mg} / \mathrm{ml}$ protease XXIII (Sigma) dissolved in dissociation solution. After enzyme treatment, the tissue pieces were rinsed in ice-cold dissociation solution containing $1 \mathrm{mg} / \mathrm{ml}$ trypsin inhibitor and $1 \mathrm{mg} / \mathrm{ml} \mathrm{BSA}$, 
A

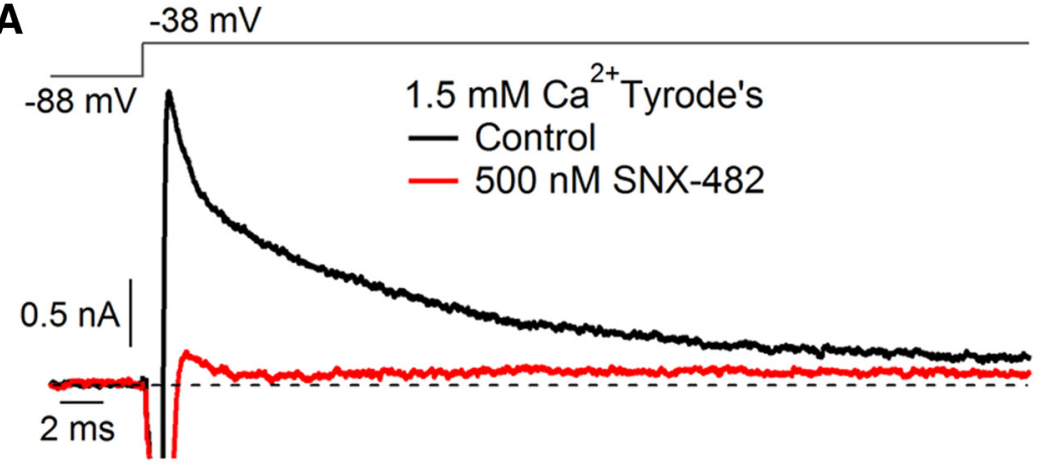

B

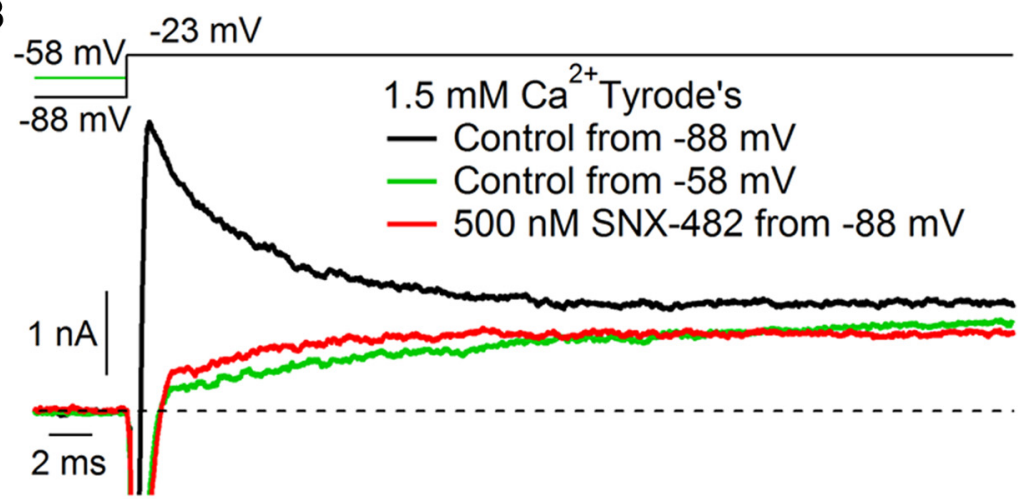

C

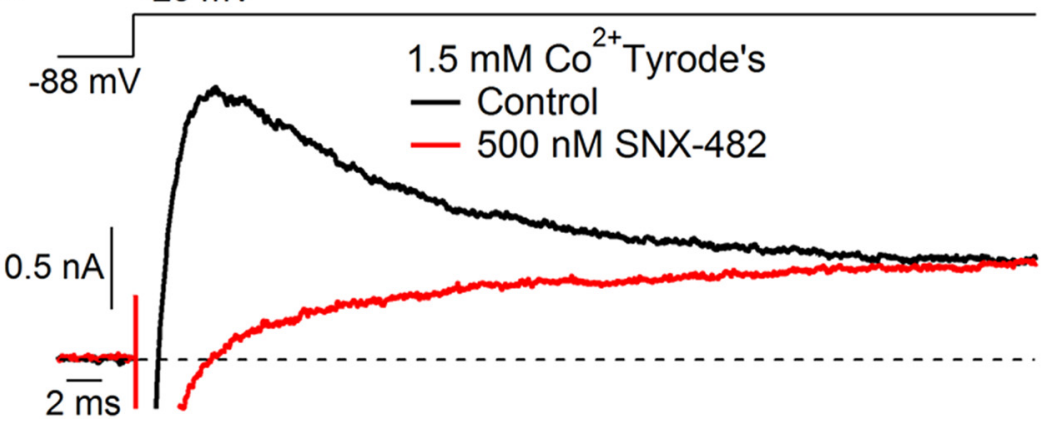

L-glutamine (ATCC) supplemented with $10 \%$ heat-inactivated FBS (Sigma), 100 units $/ \mathrm{ml}$ penicillin/streptomycin, and 400 $\mu \mathrm{g} / \mathrm{ml} \mathrm{G418}$. Cells were kept at $37^{\circ} \mathrm{C}$ in a humidified $5 \% \mathrm{CO}_{2}$ incubator and passaged every 4-7 d. Before electrophysiological experiments, cells were treated with trypsinEDTA, plated onto uncoated glass coverslips, and allowed to settle for 4-30 h. Immediately before recording, coverslips were transferred to the recording chamber containing $\mathrm{Ty}-$ rode's solution.

Experiments on cloned Kv4.2 and Cav2.3 channels were done using transient transfection of HEK-293 cells. HEK-293 cells were maintained in DMEM with L-glutamine supplemented with $10 \%$ HI-FBS and 100 units $/ \mathrm{ml}$ penicillin/streptomycin. Cells were transiently transfected 1-2 d before recordings using the PolyJet DNA Transfection Reagent (SignaGen) according to manufacturer's instructions. Kv4.2 channels were transiently expressed in HEK-293 cells using plasmids generously provided by Dr. Jeanne Nerbonne (Washington University School of Medicine, St. Louis, MO), and Cav2.3 channels were transiently expressed in HEK-293 cells using plasmids for $\alpha 1 \mathrm{E}, \alpha 2 \delta$, and $\beta 1 \mathrm{~b}$ generously provided by $\mathrm{Dr}$. Gerald Zamponi (University of Calgary, Calgary, Alberta, Canada). In both cases, eGFP was included as a transfection marker.

Electrophysiological recording. Most experiments used solutions designed to approximate physiological conditions. Standard external solution was Tyrode's solution containing (in $\mathrm{mm}$ ) the following: $151 \mathrm{NaCl}, 10$ HEPES, 13 glucose, $1.5 \mathrm{CaCl}_{2}, 1 \mathrm{MgCl}_{2}, 3.5 \mathrm{KCl}, \mathrm{pH}$ adjusted to 7.4 with $\mathrm{NaOH}$. For experiments on potassium currents in the absence of calcium entry, we used an external solution in which calcium was replaced by $1.5 \mathrm{~mm}$ cobalt, and in some experiments (as noted in figure legends) $1 \mu \mathrm{M}$ TTX was added to block sodium currents. Experiments on potassium currents in both native neurons and HEK-293 cells used an internal solution containing (in $\mathrm{mm})$ the following: $122 \mathrm{~K}$-methanesulfonate, $9 \mathrm{NaCl}, 9$ HEPES, 0.18 EGTA, $0.036 \mathrm{CaCl}_{2}$, $0.27 \mathrm{MgCl}_{2}, 4 \mathrm{MgATP}, 14$ creatine phosphate (Tris salt), 0.3 GTP (Tris salt), pH 7.4. In experiments on cloned Cav2.3 channels, re-

where they were stored until immediately before recording. Cells were used within $8 \mathrm{~h}$ of dissection. Just before recording, chunks of tissue were gently triturated in dissociation solution using a fire-polished Pasteur pipette to free individual cells. The resulting suspension was dispersed into the recording chamber. The cells were allowed to settle for 10-15 min, after which time the recording chamber was flooded with Tyrode's solution. Most recordings were made from neurons isolated from mice expressing eGFP under control of the tyrosine hydroxylase promoter (Sawamoto et al., 2001), kindly provided by Dr. Kazuto Kobayashi (Fukushima Medical University, Fukushima, Japan). This allowed unambiguous identification of dopaminergic neurons. Some recordings were also made from neurons from wild-type Swiss-Webster mice, in which case dopaminergic neurons could be identified by their large size and prominent $\mathrm{I}_{\mathrm{A}}$ currents. SNX-482 inhibited $\mathrm{I}_{\mathrm{A}}$ identically in neurons from wild-type mice and from the TH-eGFP mouse line.

Heterologous expression of Kv4.3, Kv4.2, and Cav2.3. HEK-293 cells stably expressing Kv4.3 (Eghbali et al., 2002) were kindly provided by Dr. Ligia Toro (David Geffen School of Medicine at University of California, Los Angeles, CA). Cells were maintained in DMEM with cordings were done in an external solution containing (in $\mathrm{mm}$ ) the following: 155 TEA Cl, $5 \mathrm{BaCl}_{2}, 10$ HEPES, 13 glucose, $\mathrm{pH}$ adjusted to 7.4 with TEA-OH and an internal solution containing (in $\mathrm{mm}$ ) the following: $126 \mathrm{CsCl}, 1.8 \mathrm{MgCl}_{2}, 0.09 \mathrm{EGTA}, 0.018 \mathrm{CaCl}_{2}, 4 \mathrm{MgATP}$, 14 creatine phosphate (Tris salt), 0.3 GTP (Tris salt), 9 HEPES, pH 7.4. Most experiments using dopaminergic neurons were done at $34^{\circ} \mathrm{C}$, with a few done at $37^{\circ} \mathrm{C}$ (including those in Fig. $5 \mathrm{~A}$ ) and a few at room temperature $\left(23^{\circ} \mathrm{C}\right)$. The results were the same at the different temperatures, except that inhibition of $\mathrm{I}_{\mathrm{A}}$ was faster at $34^{\circ} \mathrm{C}$ or $37^{\circ} \mathrm{C}$ (complete within $\sim 5 \mathrm{~s}$ ) than at room temperature $(\sim 15 \mathrm{~s})$. Experiments testing the effect of SNX-482 on total noninactivating potassium current (see Fig. 5A) were done using cobalt substituted for calcium (to eliminate any possible effects from blocking calcium current) and with $1 \mu \mathrm{M}$ TTX to block sodium currents; these experiments were done at both room temperature and at $37^{\circ} \mathrm{C}$ and were pooled as there was no statistically significant difference.

Recordings from cloned channels in HEK-293 cells were done at room temperature. 


\section{A Kv4.3 in HEK-293}
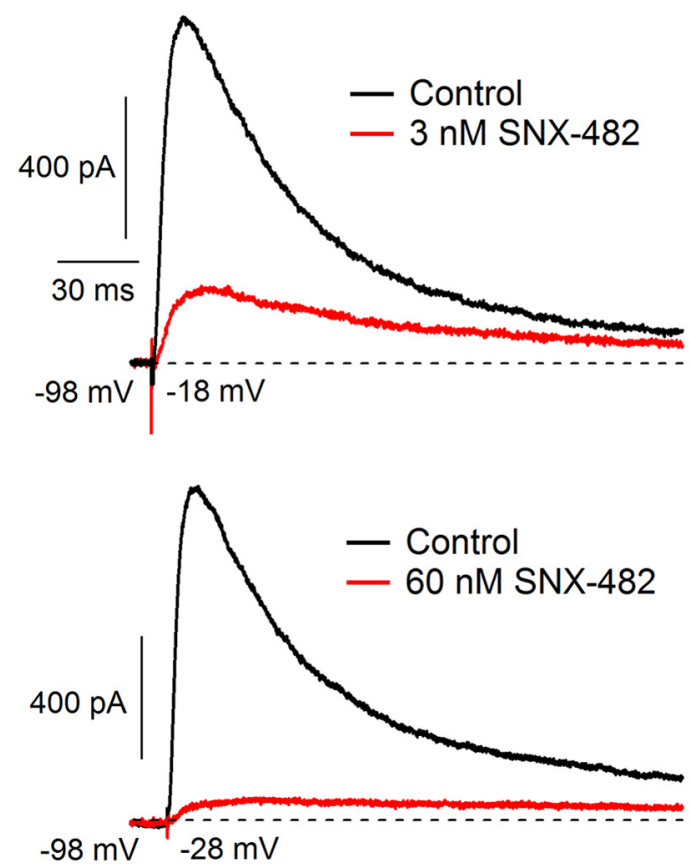

B Cav2.3 in HEK-293

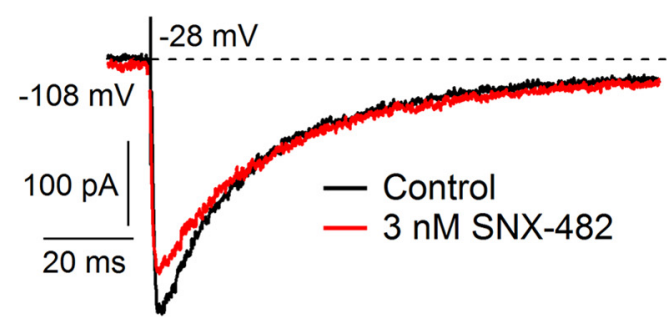

Figure 2. SNX-482 inhibition of cloned Kv4.3 and Cav2.3 channels. $\boldsymbol{A}$, Effect of $3 \mathrm{~nm}$ (top) and $60 \mathrm{~nm}$ (bottom) SNX-482 on current carried by cloned Kv4.3 channels expressed in HEK-293 cells. $\boldsymbol{B}$, Effect of $3 \mathrm{~nm}$ (top) and $60 \mathrm{~nm}$ (bottom) SNX-482 on current carried by cloned Cav2.3 channels expressed in HEK-293 cells. Recordings at $23^{\circ} \mathrm{C}$.

Recording pipettes were pulled from borosilicate glass (VWR International) using a Sutter Instruments P-97 horizontal puller and wrapped with Parafilm to reduce pipette capacitance. Pipette resistances ranged from 1 to $3 \mathrm{~m} \Omega$. Data recorded with the potassium methanesulfonatebased internal solution have been corrected to reflect a $-8 \mathrm{mV}$ liquid junction potential between this solution and the Tyrode's solution in which the current was set to zero at the beginning of the experiment, measured using a flowing $3 \mathrm{M} \mathrm{KCl}$ reference electrode as described by Neher (1992).

Whole-cell voltage-clamp recordings were performed using a Molecular Devices 700B amplifier (Molecular Devices), a Digidata 1322A A/D converter (Molecular Devices), and pCLAMP9.2 software (Molecular Devices). Pipette capacitance and series resistance (70\%-90\%) were compensated using the amplifier circuitry. Signals were filtered at $10 \mathrm{kHz}$ and sampled at 10 or $20 \mu$ s.

In most experiments, after a G $\Omega$ seal and whole-cell configuration were established, the cell was lifted off the bottom of the recording chamber and placed in front of a set of gravity flow perfusion pipes to facilitate rapid solution exchange. In experiments using toxin concentrations $<100 \mathrm{~nm}, 1 \mathrm{mg} / \mathrm{ml}$ cytochrome C or BSA was added to all experimental solutions to reduce toxin loss from binding to the tubing. In some experiments on HEK-293 cells, recordings were made with cells attached to the coverslip, and toxin was applied directly in the bath.

Synthetic SNX-482 was purchased from the Peptide Institute, and purified recombinant SNX-482 was purchased from Alomone Labs. Peptide from the two sources gave identical results and inhibited Cav2.3 channels with similar potency as originally reported (Newcomb et al., 1998).

Analysis. Data analysis was done in Igor Pro 6.12A (WaveMetrics) using DataAccess (Bruxton Software) to read pCLAMP files. Current records were corrected for linear capacitative and leak current using 5 or $10 \mathrm{mV}$ hyperpolarizing steps to define linear capacitance and leak currents and then subtracting appropriately scaled currents. In some cases, correction for capacity transients was imperfect as a result of amplifier saturation for large voltage steps and $100-200 \mu$ s of the current record is blanked in the displayed records. In some figures, current records were digitally filtered with a low-pass filter corresponding to a 4-pole Bessel filter with a corner frequency of $2 \mathrm{kHz}$. Data are presented as mean \pm SEM; $p$ values were calculated using paired or unpaired Student's $t$ test or the Mann-Whitney-Wilcoxon test.

\section{Results}

SNX-482 inhibits $\mathrm{I}_{\mathrm{A}}$ in acutely dissociated SNc dopaminergic neurons

We began by examining total potassium current in acutely dissociated SNc dopaminergic neurons using whole-cell voltageclamp recordings. Prominent A-type current is a hallmark of SNc dopaminergic neurons (Liss et al., 1999, 2001; Hahn et al., 2003; Durante et al., 2004). With physiological ionic conditions, a voltage step from $-88 \mathrm{mV}$ to $-38 \mathrm{mV}$ elicited a transient inward sodium current followed by a large outward current that inactivated over tens of milliseconds, typical of $\mathrm{I}_{\mathrm{A}}$ in $\mathrm{SNc}$ neurons (Fig. 1). In testing for a possible contribution to overall potassium current from calcium-activated potassium channels, we examined the effects of a series of calcium channel blockers. Surprisingly, $500 \mathrm{~nm}$ SNX-482, a commonly used inhibitor of Cav2.3 calcium channels, inhibited the transient outward current almost completely (Fig. 1A). Overall, 500 nM SNX-482 reduced the peak of the total outward potassium current evoked by a step from $-88 \mathrm{mV}$ to $-23 \mathrm{mV}$ to $36 \pm 4 \%$ of its control value $(n=8, p=$ $\left.9.1 \times 10^{-7}\right)$. The inactivating component of outward current (defined as the peak current minus the current remaining at the end of a $1 \mathrm{~s}$ test pulse) was nearly abolished by $500 \mathrm{~nm}$ SNX-482 (reduced to $7 \pm 3 \%$ of the control value, $n=8, p=1.5 \times 10^{-8}$ ). The dramatic effect of SNX-482 on potassium current was unexpected because R-type calcium channels account for at most $\sim 15 \%$ of overall calcium current in these cells (Cardozo and Bean, 1995; Durante et al., 2004). Also, it would be very surprising if so much of the overall potassium current were calciumactivated, and the inactivation kinetics of the current inhibited by SNX-482 seem to identify it as $\mathrm{I}_{\mathrm{A}}$. 
Kv4.3 in HEK-293

A
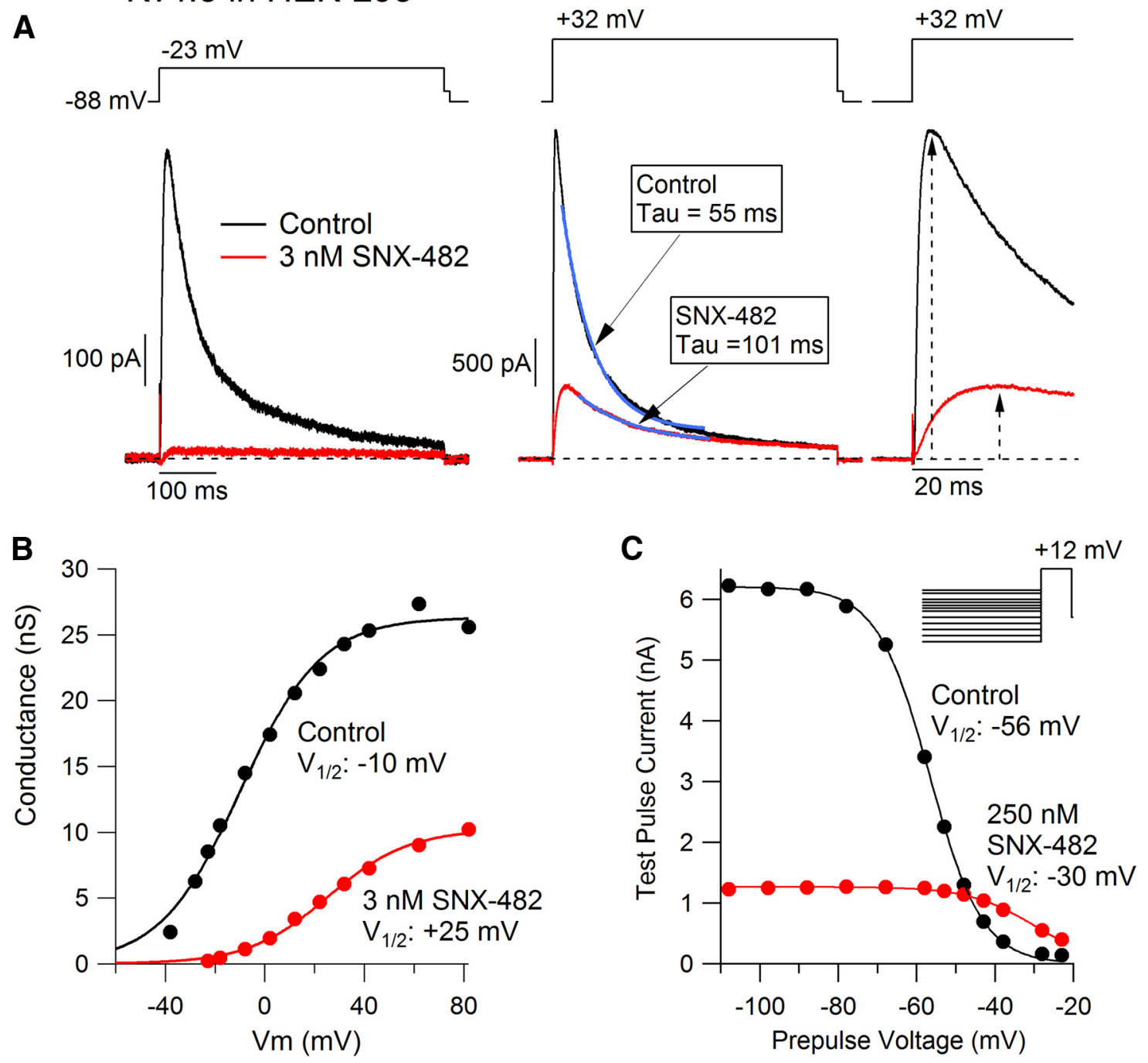

Figure 3. Altered gating of Kv4.3 channels induced by SNX-482. A, Effect of $3 \mathrm{~nm}$ SNX-482 on current carried by Kv4.3 channels for test pulses to $-23 \mathrm{mV}$ (left) or to $32 \mathrm{mV}$ (middle). Currents at $32+\mathrm{mV}$ are superimposed with single exponential functions fit to the inactivating phase (blue traces). Right, Currents at $+32 \mathrm{mV}$ shown on expanded time scale to illustrate slowing of activation by SNX-482. Dashed lines with arrows indicate time of peak current (5.5 ms in control and $25.7 \mathrm{~ms}$ with SNX-482). B, Conductance-voltage relation of cloned Kv4.3 channels in control (black) and after application of $3 \mathrm{~nm}$ SNX-482 (red). Conductance was measured from peak current evoked from a holding potential of $-88 \mathrm{mV}$ using a reversal potential of $-90 \mathrm{mV}$ and normalized to the maximum value in control. Solid black line indicates fit of control data to Boltzmann function, $G_{\max } /\left(1+\exp \left(-\left(V-V_{h}\right) / k\right)\right)$, where $G_{\max }=26.3 \mathrm{nS}, V_{h}=-9.8 \mathrm{mV}$ is the midpoint, and $\mathrm{k}=16.2$ $\mathrm{mV}$ is the slope factor. Solid red line indicates fit of the data in $3 \mathrm{~nm} S \mathrm{SNX}-428$, with $\mathrm{G}_{\max }=10.2 \mathrm{nS}, \mathrm{V}_{\mathrm{h}}=+25.4 \mathrm{mV}$, and $\mathrm{k}=16.1 \mathrm{mV}$. C, Voltage dependence of inactivation of Kv4.3 channels determined using $1 \mathrm{~s}$ prepulses and a test pulse to $12 \mathrm{mV}$. Peak test pulse current is plotted versus prepulse voltage for recordings in control (black) and after applying $250 \mathrm{~nm}$ SNX-482 (red). Solid black line indicates fit of control data to Boltzmann function, $\mathrm{I}_{\max } /\left(1+\exp \left(\left(\mathrm{V}-\mathrm{V}_{\mathrm{h}}\right) / \mathrm{k}\right)\right)$, where $\mathrm{I}_{\max }=6.2 \mathrm{nA}, \mathrm{V}_{\mathrm{h}}=-56.8 \mathrm{mV}$ is the midpoint, and $\mathrm{k}=6.7 \mathrm{mV}$ is the slope factor. Solid red line indicates fit of the data in $250 \mathrm{~nm} \mathrm{SNX}-428$, with $\mathrm{I}_{\max }=1.3 \mathrm{nS}, \mathrm{V}_{\mathrm{h}}=-30.0 \mathrm{mV}$, and $\mathrm{k}=8.3 \mathrm{mV}$. Recordings at $23^{\circ} \mathrm{C}$.

A defining characteristic of $\mathrm{I}_{\mathrm{A}}$ is its sensitivity to inactivation by moderately depolarized holding or conditioning voltages (Jerng et al., 2004). Consistent with this property, the transient component of outward current evoked by a step to $-23 \mathrm{mV}$ was completely eliminated by a $1 \mathrm{~s}$ conditioning step to $-58 \mathrm{mV}$ (Fig. 1B). Application of $500 \mathrm{~nm}$ SNX-482 almost completely inhibited the transient outward current that was sensitive to the depolarized conditioning voltage (Fig. 1B). This suggests that $\mathrm{I}_{\mathrm{A}}$ is selectively reduced by SNX-482.

$\mathrm{I}_{\mathrm{A}}$ in SNc dopamine neurons is mediated by Kv4.3 channels (Liss et al., 2001; Hahn et al., 2003). Kv4 channels associate with multiple auxiliary subunits, including Kv4 channel interacting proteins (KChIPs), which regulate the functional properties and magnitude of macroscopic Kv4 current (An et al., 2000; Holmqvist et al., 2002; Shibata et al., 2003). SNc dopaminergic neurons contain mRNA for both Kv4.3 and KChIP3.1T, but for no other Kv4 $\alpha$ subunits or for KChIPs 1, 2, or 4 (Liss et al., 2001). KChIPs are calcium binding proteins, and their modulation of currents through Kv4 channels includes both calcium-dependent and calcium-independent actions (Patel et al., 2002). In cerebellar stellate cells, calcium entry through T-type (Cav3) calcium channels appears to be selectively coupled to KChIP regulation of Kv4 channels (Anderson et al., 2010), and in CA1 pyramidal neurons, blocking calcium entry through SNX-482-sensitive R-type calcium channels has been reported to enhance EPSPs by reducing availability of Kv4.2 channels (Wang et al., 2014). Accordingly, the reduction of $\mathrm{I}_{\mathrm{A}}$ by SNX-482 could, in principle, be explained if calcium entry through R-type calcium channels regulated Kv4 function via KChIP3, although, as noted, R-type calcium channels account for only a small fraction of total calcium current in these cells. 


\section{Kv4.2 in HEK-293}
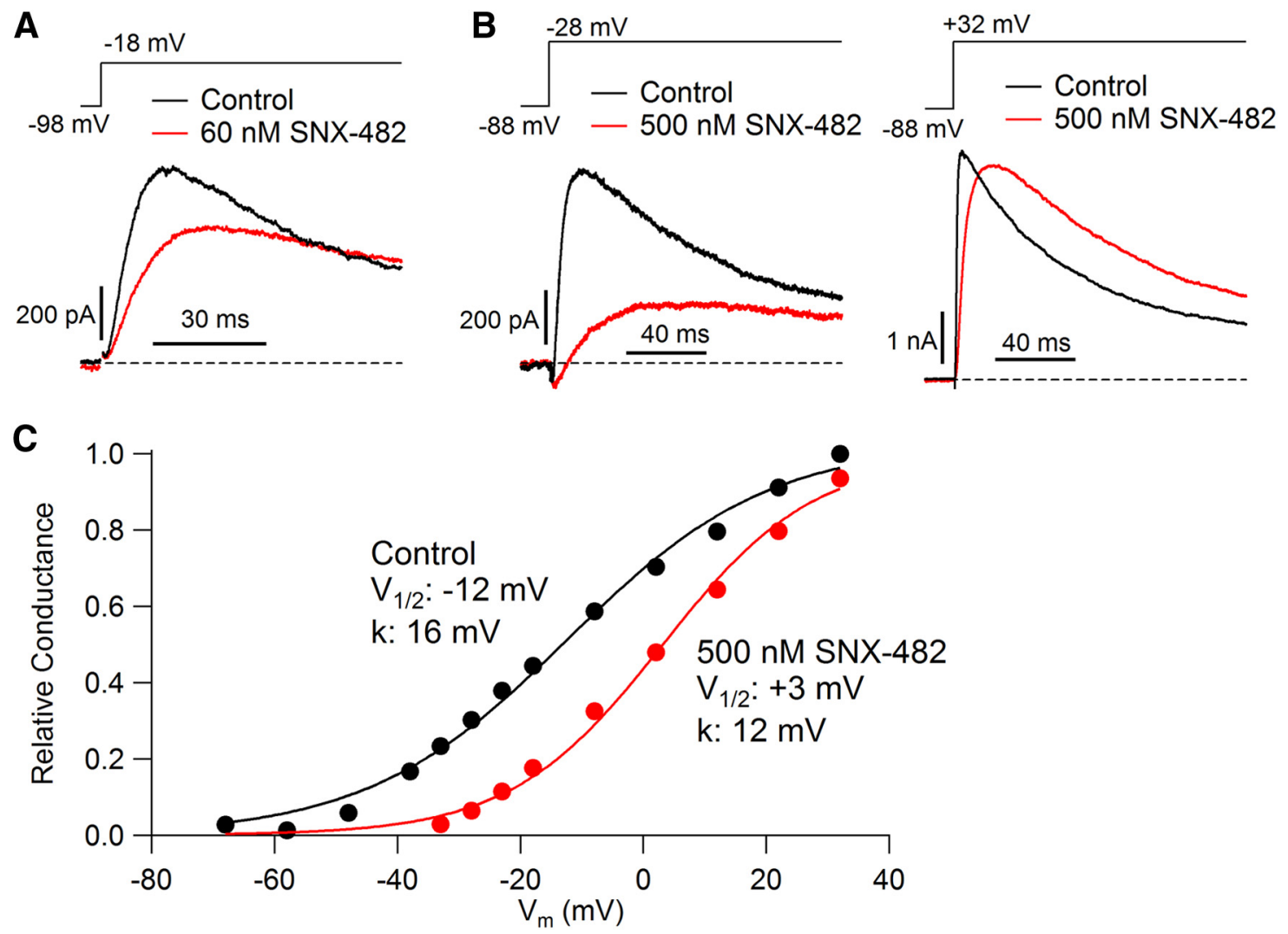

Figure 4. Effect of SNX-482 on cloned Kv4.2 channels. A, Effect of $60 \mathrm{~nm}$ SNX-482 on Kv4.2-mediated current evoked by a depolarization from -98 to $-18 \mathrm{mV}$. $\boldsymbol{B}$, Effect of $500 \mathrm{~nm}$ SNX-482 on Kv4.2 current evoked by steps to $-28 \mathrm{mV}$ (left) or $32 \mathrm{mV}$ (right). C, Conductance-voltage relation of cloned Kv4.2 channels in control (black) and in $500 \mathrm{~nm}$ SNX-482 (red). Conductance was measured from peak current evoked from a holding potential of $-98 \mathrm{mV}$ using a reversal potential of $-90 \mathrm{mV}$ and normalized to the maximum value in control. Recordings at $34^{\circ} \mathrm{C}$.

To test whether the effects of SNX-482 on $\mathrm{I}_{\mathrm{A}}$ reflect inhibition of calcium entry, we performed experiments using external solutions in which calcium was replaced with equimolar cobalt. In the absence of calcium influx, $\mathrm{I}_{\mathrm{A}}$ was still present, and it was still completely inhibited by the application of $500 \mathrm{~nm}$ SNX-482 (Fig. $1 C)$. Overall, when using external solutions with cobalt completely replacing calcium, the inactivating component of outward current evoked by a step from $-88 \mathrm{mV}$ to $-18 \mathrm{mV}$ was reduced by $500 \mathrm{~nm}$ SNX-482 to $10 \pm 3 \%$ of its control value $(n=11 ; p=$ $\left.3 \times 10^{-11}\right)$. Thus, the reduction of $\mathrm{I}_{\mathrm{A}}$ by SNX-482 is not secondary to inhibition of Cav2.3 channels.

\section{SNX-482 inhibits current through cloned Kv4.3 channels}

To test the effects of SNX-482 on Kv4.3 channels in isolation, we examined currents in HEK-293 cells stably expressing Kv4.3 channels (Eghbali et al., 2002). The transient outward current in these cells was dramatically reduced by low concentrations of SNX-482 (Fig. 2A). In collected results, 3 nM SNX-482 reduced the peak current evoked by a step from $-88 \mathrm{mV}$ to $-18 \mathrm{mV}$ to $37 \pm 8 \%$ of its control value $(n=6 ; p=0.0004)$. Application of $60 \mathrm{nM} \mathrm{SNX}-482$ reduced peak current to $7 \pm 2 \%$ of its control value $\left(n=5 ; p=4 \times 10^{-7}\right)$.

To verify that the samples of toxin we used had the expected effect on Cav2.3 channels, we examined its effects on currents in HEK-293 cells expressing Cav2.3 $\alpha$-subunits and the auxiliary calcium channel subunits $\alpha 1 \delta$ and $\beta 1 \mathrm{~b}$. Consistent with previous reports (Newcomb et al., 1998; Bourinet et al., 2001), SNX-482 inhibited the current through Cav2.3 channels (Fig. 2B) with moderate potency. Under our conditions, $60 \mathrm{~nm}$ SNX-482 reduced the current to $52 \pm 14 \%$ of its control value $(n=3)$. Thus, SNX-482 inhibits Kv4.3 channels $\sim 20$ times more potently than Cav2.3 channels.

\section{SNX-482 shifts the voltage dependence and slows activation} of Kv4.3 channels

To explore the mechanism by which SNX-482 inhibits Kv4.3 channels, we examined the effect of the toxin on the kinetics and voltage dependence of channel gating. Figure $3 A$ shows currents evoked before and after application of $3 \mathrm{nM}$ SNX-482. In this cell, current evoked by a depolarization to $-23 \mathrm{mV}$ was inhibited nearly completely by $3 \mathrm{~nm}$ SNX-482, but current evoked by a large depolarization to $+32 \mathrm{mV}$ was inhibited only partially (to $22 \%$ of control). As suggested by this comparison, SNX-482 shifted the voltage dependence of activation of $\mathrm{Kv} 4.3$ channels to more depolarized voltages (Fig. 3B). Overall, $3 \mathrm{~nm}$ SNX-482 shifted the half-activation potential from $+1 \pm 1 \mathrm{mV}$ in control to $+31 \pm$ $3 \mathrm{mV}$ in toxin $(n=5 ; p=0.001)$, with little change in slope factor $(15.7 \pm 0.6 \mathrm{mV}$ in control, $16.7 \pm 0.6 \mathrm{mV}$ in SNX-482; $p=0.18$ ). However, the reduction of current is not only the result of the shift in the voltage dependence of activation because there was also a substantial reduction in the peak conductance evoked at strongly depolarized voltages (Fig. $3 B$ ). On average, the peak conductance evoked by a step to $82 \mathrm{mV}$ was reduced to $56 \pm 7 \%$ of its control value by $3 \mathrm{~nm} \mathrm{SNX}-482(n=5 ; p=0.004)$.

Activation of Kv4.3 current was slowed by SNX-482 (Fig. 3A, right). The current evoked by a step from $-88 \mathrm{mV}$ to $+32 \mathrm{mV}$ 
A

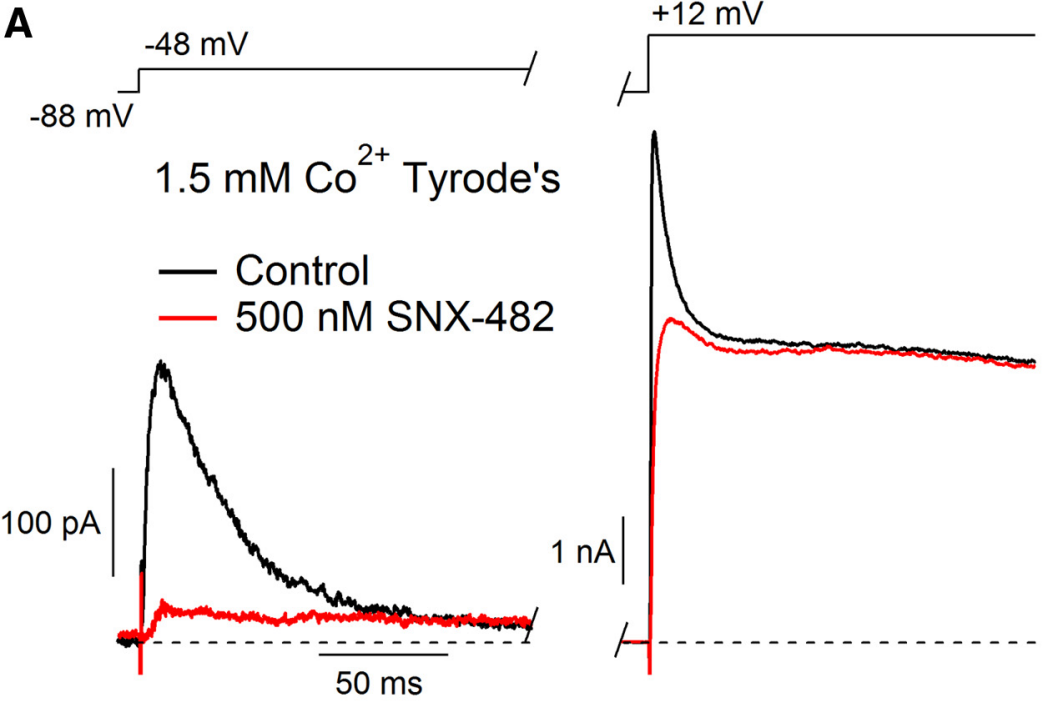

B

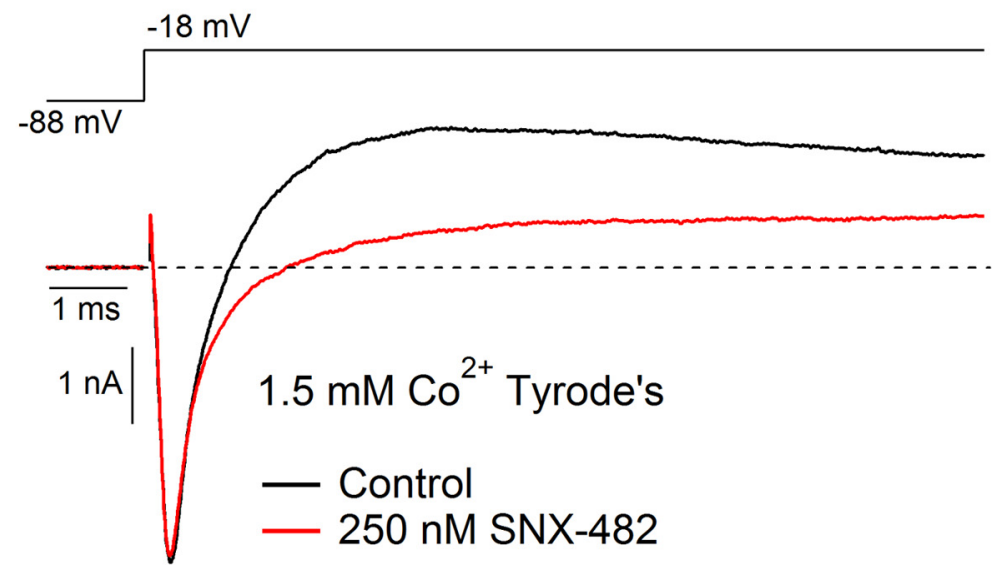

Figure 5. Selectivity of $S N X-482$ for $\mathrm{I}_{A}$ in $S N$ c dopamine neurons. $A$, Currents evoked by depolarizations from $-88 \mathrm{mV}$ to -48

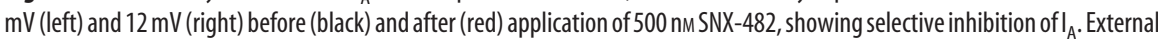
solution contained cobalt (replacing calcium) to avoid possible effects from inhibition of calcium channels and $1 \mu \mathrm{M}$ TTX to block sodium channels. Recording at $37^{\circ} \mathrm{C}$. , Currents evoked by a depolarization from $-88 \mathrm{mV}$ to $-18 \mathrm{mV}$ before (black) and after (red) application of $250 \mathrm{~nm}$ SNX-482 showing lack of effect on sodium current. External solution contained cobalt (replacing calcium). Recording at $34^{\circ} \mathrm{C}$.

reached a peak at $8 \pm 2 \mathrm{~ms}$ in control but at $27 \pm 2 \mathrm{~ms}$ in $3 \mathrm{nM}$ SNX-482 $\left(n=12, p=2.1 \times 10^{-6}\right)$. Inactivation was also slower in the presence of SNX-482. In control, decay of the current at + $32 \mathrm{mV}$ could be fairly well fit by a single exponential, with average time constant $46 \pm 4 \mathrm{~ms}$, whereas in $3 \mathrm{~nm} \mathrm{SNX}-482$, the time constant was increased to $154 \pm 23 \mathrm{~ms}(n=12, p=0.0007)$. SNX-482 also shifted inactivation to more depolarized voltages. In control, the midpoint of inactivation assayed by a test step to + $12 \mathrm{mV}$ after $1 \mathrm{~s}$ prepulses was $-61 \pm 1 \mathrm{mV}$, whereas in $250 \mathrm{~nm}$ $\mathrm{SNX}-482$, it was shifted to $-32 \pm 4 \mathrm{mV}(n=6, p=0.0017)$.

\section{SNX-482 also inhibits Kv4.2 channels}

Kv4.2 channels are expressed in many brain regions and make the major contribution to somatodendritic $\mathrm{I}_{\mathrm{A}}$ in hippocampal and neocortical pyramidal cells, some cerebellar granule cells, and other cell types (Serôdio and Rudy, 1998; Song et al., 1998; Rhodes et al., 2004; Chen et al., 2006; Kim et al., 2007). Because of its enrichment in dendrites, Kv4.2 is thought to participate especially in integration of synaptic inputs and regulation of action potential backpropagation (Sheng et al., 1992; Hoffman et al., 1997). We tested the effects of SNX-482 on cloned Kv4.2 channels expressed in HEK-293 cells. Kv4.2 current was inhibited by SNX-482 in a manner qualitatively similar to Kv4.3 (Fig. 4). However, higher toxin concentrations were required, and the resulting inhibition was less pronounced. Peak current evoked by a step to $-18 \mathrm{mV}$ was reduced to $84 \pm 4 \%$ of its control value by $60 \mathrm{nM}$ SNX-482 $(n=9 ; p=0.002)$. This value, however, underestimates the effect of SNX-482 early in the depolarization because SNX-482 markedly slowed the kinetics of activation of Kv4.2 currents (Fig. $4 A, B$ ), as seen for Kv4.3 channels. In control conditions, current evoked by a step to $-18 \mathrm{mV}$ reached its peak at $21 \pm 1 \mathrm{~ms}$,

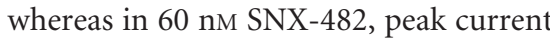
was at $34 \pm 1 \mathrm{~ms}\left(n=9 ; p=4 \times 10^{-5}\right)$.

Similar to the effects of SNX-482 on $\mathrm{Kv} 4.3$, inhibition of Kv4.2 channels was also voltage dependent (Fig. $4 B$ ), resulting in a shift in the voltage dependence of activation (Fig. 4C). However, the change in the midpoint of activation was smaller for Kv4.2 channels than for Kv4.3 channels. On average, $500 \mathrm{~nm}$ SNX-482 shifted the midpoint of Kv4.2 activation by $13.7 \pm 1.9 \mathrm{mV}(n=6, p=0.0009)$.

For Kv4.2 currents evoked by large depolarizations, SNX-482 had relatively little effect on peak current but slowed activation (Fig. 4B, right). Inactivation was also slowed, and the result was a "crossover" of the current, so that late in the depolarizing step, the current in SNX-482 was actually larger than it had been in control (Fig. $4 B$, right). Decay of the current with inactivation could be described with a single exponential function. For a step to $+32 \mathrm{mV}$, the time constant of decay increased from $52 \pm$ $4 \mathrm{~ms}$ in control to $101 \pm 13 \mathrm{~ms}$ in $500 \mathrm{nM}$ SNX-482 $(n=6, p=0.0059)$.

\section{Selectivity for $\mathrm{I}_{\mathrm{A}}$}

To explore the selectivity of SNX-482 for inhibiting $\mathrm{I}_{\mathrm{A}}$ versus other native potassium currents, we examined its effects on other voltage-activated currents present in SNc dopaminergic neurons, using cobalt-containing external solution to avoid contributions from calcium or calcium-activated currents. SNX-482 was highly selective for inhibiting the low-threshold, rapidly inactivating component of current attributable to $\mathrm{I}_{\mathrm{A}}$ (Fig. 5A). After application of $500 \mathrm{~nm}$ SNX-482, the sustained current evoked by a step from $-88 \mathrm{mV}$ to $+12 \mathrm{mV}$ was $95 \pm 4 \%$ its control magnitude, similar to the small changes that took place independent of toxin application ( $98 \pm 1 \% ; n=5 ; p=0.15)$. Similarly, SNX-482 had little or no effect on the transient sodium current (Fig. 5B). Overall, peak sodium current in 250 or 500 nM SNX-482 was $94 \pm 3 \%$ its control value $(n=7)$, little different from time-dependent reduction in currents recorded in control $(97 \pm 1 \%, n=3 ; p=$ 0.52 ). Thus, at least among the native sodium and potassium currents present in SNc neurons, the effect of SNX-482 appeared to be highly selective for $\mathrm{I}_{\mathrm{A}}$. 


\section{Discussion}

We found both native A-type current in midbrain dopamine neurons and cloned Kv4 channels to be potently inhibited by the tarantula toxin SNX-482, which is currently widely used as a selective inhibitor of Cav2.3 channels. Native $\mathrm{I}_{\mathrm{A}}$ in $\mathrm{SNc}$ dopamine neurons, thought to be mediated by Kv4.3 channels (Liss et al., 2001), was inhibited completely by $250-500 \mathrm{~nm} \mathrm{SNX}-482$. SNX482 inhibited cloned $\mathrm{Kv} 4.3$ channels with an $\mathrm{IC}_{50}$ of $<3 \mathrm{~nm}$, both by shifting the voltage dependence of channel opening to more depolarized voltages and by reducing current elicited by maximal depolarizations. The toxin also inhibited cloned Kv4.2 channels by shifting the voltage dependence of gating to depolarized voltages, although the effect was less potent and less dramatic than on Kv4.3 channels. In addition to the shift in voltage dependence, the activation kinetics of both Kv4.2 and Kv4.3 were slowed by the toxin. The shift of voltage dependence and slowing of activation are similar to the effects of SNX-482 on gating of Cav2.3 channels (Bourinet et al., 2001). For both Kv4.3 and Cav2.3, inhibition additionally involves substantial reduction of currents evoked by the strongest depolarizations. This effect was both more potent and more complete for SNX-482 action on Kv4.3 currents.

In contrast to the striking reduction of $\mathrm{I}_{\mathrm{A}}$ in dopamine neurons, the sodium current and the other potassium currents in these cells did not appear to be affected by the toxin. This is consistent with previous data showing a lack of effect on a wide variety of native potassium currents in other cell types (Newcomb et al., 1998). Thus, among potassium channels, the effect of SNX-482 on Kv4 family channels appears to be highly selective.

Structurally, SNX-482 belongs to the family of "inhibitory cystine knot" (ICK) peptide toxins that includes hanatoxin and grammotoxin. These peptides contain six cysteine residues that form three disulfide bonds at the core of the molecule and have substantial amino acid similarity in the rest of the molecule (Swartz, 2007). Most ICK toxins that inhibit voltage-dependent ion channels are gating-state modifiers that partition into the cell membrane and stabilize closed states of the channels through interactions with the voltage-sensing domains and the lipid environment (Swartz and MacKinnon, 1995; Escoubas and Rash, 2004; Lee and MacKinnon, 2004; Jung et al., 2005; Swartz, 2007). Many peptides in this family inhibit activation of more than one type of channel, consistent with general conservation of the voltage-sensing regions of voltage-dependent ion channels. Several, including hanatoxin and grammotoxin, are known to inhibit gating of individual types of potassium channels and calcium channels (Li-Smerin and Swartz, 1998). Interestingly, although SNX-482 interacts fairly potently with both Kv4.3 and Cav2.3 channels, it has substantial selectivity against other subtypes of both potassium and calcium channels. Among calcium channels, SNX-482 has 10-fold selectivity for Cav2.3 over other types of calcium channels (Newcomb et al., 1998; Bourinet et al., 2001); among potassium channels, SNX-482 fails to have significant activity against the mixture of non- $\mathrm{I}_{\mathrm{A}}$ potassium currents in native midbrain dopamine neurons or any of the other native potassium currents tested in other cell types (Newcomb et al., 1998). The precise structural elements of channels and toxin proteins that determine sensitivity and selectivity are still unclear. However, recent work has identified the "face" of the toxin peptide of one member of the ICK family that appears to be most critical for channel interaction (Wang et al., 2004; Jung et al., 2010).
A number of peptide inhibitors of $\mathrm{Kv} 4$ channels have previously been identified. Remarkably, SNX-482 has higher potency against cloned Kv4.3 than any of the other inhibitors yet described, including phrixotoxins (Diochot et al., 1999), AmmTX3 (Vacher et al., 2002; Maffie et al., 2013), and heteropodatoxin (Sanguinetti et al., 1997). Like SNX-482, heteropodatoxin is an ICK toxin that acts by shifting activation to more depolarized potentials and by slowing inactivation (Zarayskiy et al., 2005; DeSimone et al., 2009). SNX-482 is an excellent candidate to explore the possibility of separating actions on potassium and calcium channels by systematically altering the peptide sequence in a manner similar to the alanine-scanning approach used to define residues important for binding of the structurally related tarantula toxin SGTx to Kv2 channels (Wang et al., 2004). If it proves possible to selectively eliminate actions on Cav2.3 by altering specific residues of SNX-482, the resulting peptide could be very useful as a Kv4.3 inhibitor. Alternatively, substitutions to eliminate $\mathrm{Kv} 4$ actions while retaining Cav2.3 inhibition would be equally useful.

The finding that SNX-482 inhibits Kv4 channels makes some experiments using the toxin as an R-type calcium channel blocker difficult to interpret. The effects on Kv4 channels are not problematic in cases where the toxin is used to identify components of calcium current in voltage-clamp experiments in which potassium currents are blocked. Experiments using SNX-482 to study the role of R-type calcium channels in cellular or network activity under physiological conditions are more problematic. Concerns about possible direct effects on $\mathrm{Kv} 4$ channels can be addressed to some extent by showing that the effect of SNX-482 requires signaling by intracellular calcium (Wang et al., 2014). Even stronger controls can be done by showing a lack of effect of SNX-482 in Cav2.3 $3^{-1-}$ mice, which offers a strong argument that the relevant effect is indeed mediated by Cav2.3 channels (Bloodgood and Sabatini, 2007; Giessel and Sabatini, 2011). However, development of a modified peptide engineered to remove Kv4 inhibiting activity would be far more convenient for most purposes.

\section{References}

An WF, Bowlby MR, Betty M, Cao J, Ling HP, Mendoza G, Hinson JW, Mattsson KI, Strassle BW, Trimmer JS, Rhodes KJ (2000) Modulation of A-type potassium channels by a family of calcium sensors. Nature 403 : 553-556. CrossRef Medline

Anderson D, Mehaffey WH, Iftinca M, Rehak R, Engbers JD, Hameed S, Zamponi GW, Turner RW (2010) Regulation of neuronal activity by Cav3-Kv4 channel signaling complexes. Nat Neurosci 13:333-337. CrossRef Medline

Bloodgood BL, Sabatini BL (2007) Nonlinear regulation of unitary synaptic signals by $\mathrm{CaV}(2.3)$ voltage-sensitive calcium channels located in dendritic spines. Neuron 53:249-260. CrossRef Medline

Bourinet E, Stotz SC, Spaetgens RL, Dayanithi G, Lemos J, Nargeot J, Zamponi GW (2001) Interaction of SNX-482 with domains III and IV inhibits activation gating of $\alpha 1 \mathrm{E}$ (CaV2.3) calcium channels. Biophys J 81:79-88. CrossRef Medline

Cardozo DL, Bean BP (1995) Voltage-dependent calcium channels in rat midbrain dopamine neurons: modulation by dopamine and GABAB receptors. J Neurophysiol 74:1137-1148. Medline

Chen X, Yuan LL, Zhao C, Birnbaum SG, Frick A, Jung WE, Schwarz TL, Sweatt JD, Johnston D (2006) Deletion of Kv4.2 gene eliminates dendritic A-type $\mathrm{K}^{+}$current and enhances induction of long-term potentiation in hippocampal CA1 pyramidal neurons. J Neurosci 26:12143-12151. CrossRef Medline

DeSimone CV, Lu Y, Bondarenko VE, Morales MJ (2009) S3b amino acid substitutions and ancillary subunits alter the affinity of heteropoda venatoria toxin 2 for Kv4.3. Mol Pharmacol 76:125-133. CrossRef Medline

Diochot S, Drici MD, Moinier D, Fink M, Lazdunski M (1999) Effects of phrixotoxins on the Kv4 family of potassium channels and implications for the role of Itol in cardiac electrogenesis. Br J Pharmacol 126:251-263. CrossRef Medline 
Doering CJ, Zamponi GW (2003) Molecular pharmacology of high voltageactivated calcium channels. J Bioenerg Biomembr 35:491-505. CrossRef Medline

Durante P, Cardenas CG, Whittaker JA, Kitai ST, Scroggs RS (2004) Lowthreshold L-type calcium channels in rat dopamine neurons. J Neurophysiol 91:1450-1454. Medline

Eghbali M, Olcese R, Zarei MM, Toro L, Stefani E (2002) External pore collapse as an inactivation mechanism for Kv4.3 $\mathrm{K}^{+}$channels. J Membr Biol 188:73-86. CrossRef Medline

Escoubas P, Rash L (2004) Tarantulas: eight-legged pharmacists and combinatorial chemists. Toxicon 43:555-574. CrossRef Medline

Giessel AJ, Sabatini BL (2011) Boosting of synaptic potentials and spine Ca transients by the peptide toxin SNX-482 requires alpha-1E-encoded voltage-gated Ca channels. PLoS One 6:e20939. CrossRef Medline

Hahn J, Tse TE, Levitan ES (2003) Long-term $\mathrm{K}^{+}$channel-mediated dampening of dopamine neuron excitability by the antipsychotic drug haloperidol. J Neurosci 23:10859-10866. Medline

Hille B (2001) Ion channels of excitable membranes. Sunderland, MA: Sinauer.

Hoffman DA, Magee JC, Colbert CM, Johnston D (1997) $\mathrm{K}^{+}$channel regulation of signal propagation in dendrites of hippocampal pyramidal neurons. Nature 387:869-875. CrossRef Medline

Holmqvist MH, Cao J, Hernandez-Pineda R, Jacobson MD, Carroll KI, Sung MA, Betty M, Ge P, Gilbride KJ, Brown ME, Jurman ME, Lawson D, Silos-Santiago I, Xie Y, Covarrubias M, Rhodes KJ, Distefano PS, An WF (2002) Elimination of fast inactivation in Kv4 A-type potassium channels by an auxiliary subunit domain. Proc Natl Acad Sci U S A 99:10351040. CrossRef Medline

Jerng HH, Pfaffinger PJ, Covarrubias M (2004) Molecular physiology and modulation of somatodendritic A-type potassium channels. Mol Cell Neurosci 27:343-369. CrossRef Medline

Jung HH, Jung HJ, Milescu M, Lee CW, Lee S, Lee JY, Eu YJ, Kim HH, Swartz KJ, Kim JI (2010) Structure and orientation of a voltage-sensor toxin in lipid membranes. Biophys J 99:638-646. CrossRef Medline

Jung HJ, Lee JY, Kim SH, Eu YJ, Shin SY, Milescu M, Swartz KJ, Kim JI (2005) Solution structure and lipid membrane partitioning of VSTx1, an inhibitor of the KvAP potassium channel. Biochemistry 44:6015-6023. CrossRef Medline

Kim J, Jung SC, Clemens AM, Petralia RS, Hoffman DA (2007) Regulation of dendritic excitability by activity-dependent trafficking of the A-type $\mathrm{K}^{+}$channel subunit Kv4.2 in hippocampal neurons. Neuron 54:933-947. CrossRef Medline

Lacinová L, Klugbauer N, Hofmann F (2000) Low voltage activated calcium channels: from genes to function. Gen Physiol Biophys 19:121-136. Medline

Lee SY, MacKinnon R (2004) A membrane-access mechanism of ion channel inhibition by voltage sensor toxins from spider venom. Nature 430: 232-235. CrossRef Medline

Lewis RJ, Dutertre S, Vetter I, Christie MJ (2012) Conus venom peptide pharmacology. Pharmacol Rev 64:259-298. CrossRef Medline

Li-Smerin Y, Swartz KJ (1998) Gating modifier toxins reveal a conserved structural motif in voltage-gated $\mathrm{Ca}^{2+}$ and $\mathrm{K}^{+}$channels. Proc Natl Acad Sci U S A 95:8585-8589. CrossRef Medline

Liss B, Bruns R, Roeper J (1999) Alternative sulfonylurea receptor expression defines metabolic sensitivity of K-ATP channels in dopaminergic midbrain neurons. EMBO J 18:833-846. CrossRef Medline

Liss B, Franz O, Sewing S, Bruns R, Neuhoff H, Roeper J (2001) Tuning pacemaker frequency of individual dopaminergic neurons by Kv4.3L and KChip3.1 transcription. EMBO J 20:5715-5724. CrossRef Medline

Llinás RR (1988) The intrinsic electrophysiological properties of mammalian neurons: insights into central nervous system function. Science 242: 1654-1664. CrossRef Medline

Maffie JK, Dvoretskova E, Bougis PE, Martin-Eauclaire MF, Rudy B (2013) Dipeptidyl-peptidase-like-proteins confer high sensitivity to the scorpion toxin AmmTX3 to Kv4-mediated A-type $\mathrm{K}^{+}$channels. J Physiol 591: 2419-2427. CrossRef Medline

McDonough SI (2007) Gating modifier toxins of voltage-gated calcium channels. Toxicon 49:202-212. CrossRef Medline
Neher E (1992) Correction for liquid junction potentials in patch clamp experiments. In: Methods in enzymology (Rudy B, ed), pp 123-131. San Diego: Academic.

Newcomb R, Szoke B, Palma A, Wang G, Chen Xh, Hopkins W, Cong R, Miller J, Urge L, Tarczy-Hornoch K, Loo JA, Dooley DJ, Nadasdi L, Tsien RW, Lemos J, Miljanich G (1998) Selective peptide antagonist of the class E calcium channel from the venom of the tarantula Hysterocrates gigas. Biochemistry 37:15353-15362. CrossRef Medline

Nimmrich V, Gross G (2012) P/Q-type calcium channel modulators. Br J Pharmacol 167:741-759. CrossRef Medline

Patel SP, Campbell DL, Strauss HC (2002) Elucidating KChIP effects on Kv4.3 inactivation and recovery kinetics with a minimal KChIP2 isoform. J Physiol 545:5-11. CrossRef Medline

Pringos E, Vignes M, Martinez J, Rolland V (2011) Peptide neurotoxins that affect voltage-gated calcium channels: a close-up on $\omega$-agatoxins. Toxins 3:17-42. CrossRef Medline

Rhodes KJ, Carroll KI, Sung MA, Doliveira LC, Monaghan MM, Burke SL, Strassle BW, Buchwalder L, Menegola M, Cao J, An WF, Trimmer JS (2004) KChIPs and Kv4 $\alpha$ subunits as integral components of A-type potassium channels in mammalian brain. J Neurosci 24:7903-7915. CrossRef Medline

Sanguinetti MC, Johnson JH, Hammerland LG, Kelbaugh PR, Volkmann RA, Saccomano NA, Mueller AL (1997) Heteropodatoxins: peptides isolated from spider venom that block Kv4.2 potassium channels. Mol Pharmacol 51:491-498. Medline

Sawamoto K, Nakao N, Kobayashi K, Matsushita N, Takahashi H, Kakishita K, Yamamoto A, Yoshizaki T, Terashima T, Murakami F, Itakura T, Okano H (2001) Visualization, direct isolation, and transplantation of midbrain dopaminergic neurons. Proc Natl Acad Sci U S A 98:64236428. CrossRef Medline

Serôdio P, Rudy B (1998) Differential expression of Kv4 K ${ }^{+}$channel subunits mediating subthreshold transient $\mathrm{K}^{+}$(A-type) currents in rat brain. J Neurophysiol 79:1081-1091. Medline

Sheng M, Tsaur ML, Jan YN, Jan LY (1992) Subcellular segregation of two A-type $\mathrm{K}^{+}$channel proteins in rat central neurons. Neuron 9:271-284. CrossRef Medline

Shibata R, Misonou H, Campomanes CR, Anderson AE, Schrader LA, Doliveira LC, Carroll KI, Sweatt JD, Rhodes KJ, Trimmer JS (2003) A fundamental role for KChIPs in determining the molecular properties and trafficking of Kv4.2 potassium channels. J Biol Chem 278:36445-36454. CrossRef Medline

Song WJ, Tkatch T, Baranauskas G, Ichinohe N, Kitai ST, Surmeier DJ (1998) Somatodendritic depolarization-activated potassium currents in rat neostriatal cholinergic interneurons are predominantly of the A type and attributable to coexpression of Kv4.2 and Kv4.1 subunits. J Neurosci 18:3124-3137. Medline

Swartz KJ (2007) Tarantula toxins interacting with voltage sensors in potassium channels. Toxicon 49:213-230. CrossRef Medline

Swartz KJ, MacKinnon R (1995) An inhibitor of the Kv2.1 potassium channel isolated from the venom of a chilean tarantula. Neuron 15:941-949. CrossRef Medline

Vacher H, Alami M, Crest M, Possani LD, Bougis PE, Martin-Eauclaire MF (2002) Expanding the scorpion toxin alpha-KTX 15 family with AmmTX3 from androctonus mauretanicus. Eur J Biochem 269:6037-6041. CrossRef Medline

Vink S, Alewood PF (2012) Targeting voltage-gated calcium channels: developments in peptide and small-molecule inhibitors for the treatment of neuropathic pain. Br J Pharmacol 167:970-989. CrossRef Medline

Wang JM, Roh SH, Kim S, Lee CW, Kim JI, Swartz KJ (2004) Molecular surface of tarantula toxins interacting with voltage sensors in Kv channels. J Gen Physiol 123:455-467. CrossRef Medline

Wang K, Lin MT, Adelman JP, Maylie J (2014) Distinct $\mathrm{Ca}^{2+}$ sources in dendritic spines of hippocampal CA1 neurons couple to SK and Kv4 channels. Neuron 81:379-387. CrossRef Medline

Zarayskiy VV, Balasubramanian G, Bondarenko VE, Morales MJ (2005) Heteropoda toxin 2 is a gating modifier toxin specific for voltage-gated $\mathrm{K}^{+}$channels of the Kv4 family. Toxicon 45:431-442. CrossRef Medline 